\title{
CAMBRIDGE JURALS
}

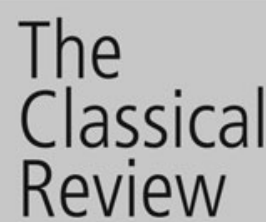

Published for The Classical Association

\section{Editor}

Mike Edwards, University of Wales Trinity Saint David, UK Roger Rees, University of St Andrews, UK

The Classical Review publishes informative reviews from leading scholars on new work covering the literatures and civilizations of ancient Greece and Rome. Publishing over 150 high quality reviews and 50 brief notes every year, The Classical Review is an indispensable reference tool, essential for keeping abreast with current classical scholarship.

\section{Price information}

is available at: http://journals.cambridge.org/car

\section{Free email alerts}

Keep up-to-date with new material - sign up at http://journals.cambridge.org/car-alerts

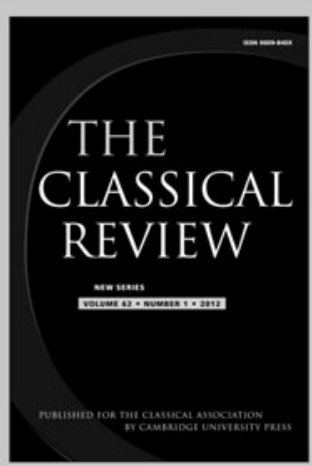

The Classical Review is available online at: http://journals.cambridge.org/car

To subscribe contact Customer Services

\section{in Cambridge:}

Phone +44 (0)1223 326070

$\mathrm{Fax}+44(0) 1223325150$

Email journals@cambridge.org

in New York:

Phone +1 (845) 3537500

$\mathrm{Fax}+1(845) 3534141$

Email

subscriptions_newyork@cambridge.org

For free online content visit: http://journals.cambridge.org/car 


\section{SUBSCRIPTION RATES}

Ramus (ISSN 0048-671X) is published twice a year in June and December. Two parts form a volume. The subscription price (excluding VAT) of volume 44 (2015), which includes print and online access, is $£ 95$ (US\$147 in the USA, Canada and Mexico, AU\$137 in Australasia) for institutions. The electronic-only price available to institutional subscribers is $£ 76$ (US\$132 in the USA, Canada and Mexico, AU\$123 in Australasia). The subscription price for individuals ordering direct from the publisher and certifying that the journal is for their personal use is $£ 27$ (US\$45 in the USA, Canada and Mexico, AU\$42 in Australasia), plus a reduced electronic-only price of $£ 16$ (US\$28 in the USA, Canada and Mexico, AU\$25 in Australasia). EU subscribers (outside the UK) who are not registered for VAT should add VAT at their country's rate. VAT-registered customers should provide their VAT-registration number. Japanese prices for institutions (including ASP delivery) are available from Kinokuniya Company Ltd., P.O. Box 55, Chitose, Tokyo 156, Japan. All prices include delivery by air where appropriate.

Orders, which must be accompanied by payment, may be sent to a bookseller, subscription agent, or direct to the publisher: Cambridge University Press, The Edinburgh Building, Shaftesbury Road, Cambridge, CB2 8RU; or in the USA, Canada and Mexico: Cambridge University Press, Journals Fulfillment Department, 100 Brook Hill Drive, West Nyack, New York, 10994-2133, USA.

\section{COPYING}

This journal is registered with the Copyright Clearance Center, 222 Rosewood Drive, Danvers, MA 01923, USA. Organisations in the USA who are registered with the C.C.C. may therefore copy material (beyond the limits permitted by sections 107 and 108 of the U.S. Copyright law) subject to payment to the C.C.C. of the per copy fee of $\$ 30$. This consent does not extend to multiple copying for promotional or commercial purposes. Code 0048-671X/2015. ISI Tear Sheet Service, 3501 Market Street, Philadelphia, PA 19104, USA, is authorised to supply single copies of separate articles for private use only. Organisations authorised by the Copyright Licensing Agency may also copy material subject to the usual conditions. For all other use, permission should be sought from Cambridge or from the North American Branch of Cambridge University Press.

The journal is included in the Cambridge Journals Online service which can be found at http://journals.cambridge.org.

This journal has been printed on FSC-certified paper and cover board. FSC is an independent, non-governmental, not-for-profit organization established to promote the responsible management of the world's forests. Please see www.fsc.org for information.

Printed by Henry Ling Ltd, Dorchester, United Kingdom 


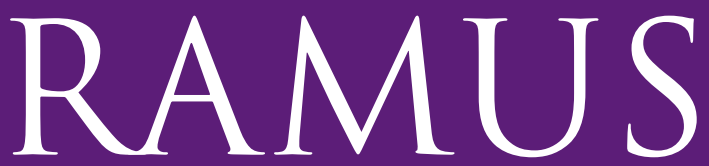

CRITICAL STUDIES IN GREEK AND ROMAN LITERATURE

CONTENTS VOL. 44 NOS. 1 \& 22015

Introduction

Sara Lindheim and Helen Morales

The Homeric Text

Barbara Graziosi and Johannes Haubold

Situating Scamander: 'Natureculture' in the lliad

Brooke Holmes

Eurykleia's Silence and Odysseus' Enormity: The Multiple Meanings of Odysseus'

Triumphs

Alexander C. Loney

Ajax and Other Objects: Homer's Vibrant Materialism

Alex Purves

'Anger Sweeter than Dripping Honey': Violence as a Problem in the Iliad William G. Thalmann

Nobody's Home: Metis, Improvisation and the Instability of Return in Homer's Odyssey

Carol Dougherty

Penelope's Foot

Mark Buchan

The 'Narrow Road' and the Ethics of Language Use in the Iliad and the Odyssey

David F. Elmer

Homer and the Sublime

James I. Porter

Counting On Epic: Mathematical Poetry and Homeric Epic in Archimedes'

Cattle Problem

Max Leventhal 